\title{
Salmonella Typhimurium - associated meningoencephalomyelitis in a foal
}

\author{
Jéssica Guerra de Oliveira ${ }^{1}$ Carolina Pantuzza Ramos ${ }^{2}$ Izabela de Assis Rocha ${ }^{1}$ (D) \\ Sóstenes Apolo Correia Marcelino ${ }^{3}$ Felipe Pierezan ${ }^{4}$ Maristela Silveira Palhares ${ }^{4}$ \\ Renata de Pino Albuquerque Maranhão ${ }^{4}$ (i) Rodrigo Otávio Silveira Silva $^{5}$ (i) \\ Raffaella Bertoni Cavalcanti Teixeira ${ }^{* *}$ (iD
}

1Programa de Pós-Graduação em Ciência Animal, Área de Concentração em Medicina e Cirurgia Veterinárias, Escola de Veterinária,
Universidade Federal de Minas Gerais (UFMG), Belo Horizonte, MG, Brasil.
2Programa de Pós-Graduação em Ciência Animal, Área de Concentração em Medicina Veterinária Preventiva, Escola de Veterinária,
Universidade Federal de Minas Gerais (UFMG), Belo Horizonte, MG, Brasil.
${ }^{3}$ Programa de Pós-Graduação em Ciência Animal, Área de Concentração em Patologia Animal, Escola de Veterinária, Universidade Federal de
Minas Gerais (UFMG), Belo Horizonte, MG, Brasil.
${ }^{4}$ Departamento de Clínica e Cirurgia Veterinárias, Escola de Veterinária, Universidade Federal de Minas Gerais (UFMG), Belo Horizonte, MG,
Brasil. E-mail: teixeiraraffa@gmail.com. *Corresponding author.
${ }^{5}$ Departamento de Medicina Veterinária Preventiva, Escola de Veterinária, Universidade Federal de Minas Gerais (UFMG), Belo Horizonte,

ABSTRACT: A 10-day old foal presented with a history of acute recumbency and generalized weakness, that progressed to seizure episodes and death. Post mortem examination revealed necrotizing and purulent omphalophlebitis and fibrinopurulent meningoencephalomyelitis. Salmonella Typhimurium was isolated from the central nervous system and determined to be the cause of the meningoencephalomyelitis. Due to the lack of evidence of gastrointestinal disease, the umbilical cord was considered the most likely portal of entry of the bacteria. The isolated S. Typhimurium was resistant to ampicillin and cephalotin, and partially resistant to enrofloxacin. These drugs are commonly used in the treatment of salmonellosis. This is the first report of S. Typhimurium affecting the brain and spinal cord of a foal. Salmonellosis should be considered a differential diagnosis in foals with neurologic signs, even in the absence of enterocolitis.

Key words: horse, salmonellosis, omphalophlebitis, meningoencephalitis, diarrhea.

Meningoencefalomielite por Salmonella Typhimurium em potro

RESUMO: Um potro de 10 dias de idade foi admitido com histórico de decúbito e fraqueza generalizada aguda, com progressão para episódios de convulsão e morte. A avaliação post mortem demonstrou onfalite necropurulenta e meningoencefalomielite fibrinopurulenta. Salmonella Typhimurium foi isolada do material purulento coletado do sistema nervoso central. A ausência de diarreia e lesões entéricas associadas à presença de onfalite sugerem que o umbigo foi possivelmente a porta de entrada do agente. $O$ isolado de $S$. Typhimurium apresentou resistência a cefalotina e ampicilina e resistência intermediária a enrofloxacina, drogas utilizadas para o tratamento de salmonelose. Este é o primeiro relato de $S$. Typhimurium levando a alterações encefálicas e medulares em potro. A salmonelose deve ser considerada, portanto, como diagnóstico diferencial em potros neonatos com alterações neurológicas, mesmo na ausência de enterocolite.

Palavras-chave: equino, salmonelose, onfaloflebite, meningoncefalite, diarreia.

Bacterial meningoencephalomyelitis is a rare condition in horses (PATTERSON-KANE et al., 2001; VIU et al., 2012), and leads to high mortality (VIU, 2012; BACH et al., 2014). Neonates are the age group more commonly affected as a consequence of septicemia (MITCHELL et al., 2006; PELLEGRINI-MAZINI \& LIVESEY, 2006; VIU et al., 2012). Escherichia coli, Streptococcus spp. and Staphylococcus aureus are commonly isolated in cases of bacterial meningitis in horses (MITCHELL et al., 2006; PELLEGRINI-MASINI \& LIVESEY,
2006). Equine salmonellosis can be asymptomatic, but is commonly associated with fever and enterocolitis, that can progress to septicemia in young animals (SMITH, 1981; JUFFO et al., 2017). Reports of meningoencephalomyelitis caused by Salmonella spp. are rare in horses (STUART et al., 1973). This article reports a case of meningoencephalomyelitis caused by Salmonella Typhimurium in a female foal, with no evidence of enterocolitis.

A 10-day-old Mangalarga Marchador foal, weighting $50 \mathrm{~kg}$, was admitted with a history 
of acute onset recumbency, generalized weakness and intermittent pedaling movements. The foal was kept with the mare in a paddock. The owner reported that the foal was bright and alert and had good appetite and normal feces the day prior to admission. There was no history of trauma and the other horses at the farm were asymptomatic. The vaccination and deworming history of the mare was unknown, as well as details about the foal's umbilical care and colostrum intake after birth. At admission the foal was in lateral recumbency and comatose. Physical exam revealed tachycardia (139 bpm), tachypnea (59 mpm), normal body temperature $\left(38,1^{\circ} \mathrm{C}\right)$, weak peripheral pulses, tacky and dry mucous membranes with increased capillary refill time ( 3 seconds) and respiratory dyspnea. Thoracic auscultation revealed no abnormal sounds. The umbilicus was larger than normal on palpation, but no discharge was noted. Palpation of the joints revealed no abnormalities. Decreased gastrointestinal sounds were noted on abdominal auscultation and no feces were passed during the exam. The foal showed intermittent generalized seizures, with increased duration and frequency during the exam. Its blood glucose was normal at $85 \mathrm{mg} / \mathrm{dl}$.

Initial therapy included fluid therapy with Ringer's lactate solution to replace losses, followed by intravenous fluids with dimethyl sulfoxide (DMSO, $1 \mathrm{~g} / \mathrm{kg}$ ) diluted in isotonic solution with $5 \%$ dextrose. Intravenous dexamethasone $(0.1 \mathrm{mg} /$ $\mathrm{kg}$ ) and diazepam at $0.05 \mathrm{mg} / \mathrm{kg}$, in attempt to control seizures, were also administered. The foal continued to deteriorate and died before institution of additional therapy, soon after admission. Due to the rapid progression to death, a blood culture to confirm bacteremia, complete blood cell count, chemistry profile and spinal fluid tap were not performed.

Post mortem examination revealed focally extensive necrotic and purulent omphalophlebitis, characterized by moderately enlarged, hyperemic umbilicus that presented miliary dark hemorrhagic lesions at cut section. The subdural space of the meninges in the brain and thoracic segment of the spinal cord were filled with moderate amounts of fibrinopurulent exudate (Figure 1A and Figure 1B). There were focally extensive areas of softening affecting the frontal lobe. Histopathology of the central nervous system (CNS) was performed and included the cortex, cerebellum, pons and thoracic spinal cord. With exception of the cortex, all sections presented severe meningeal fibrin exudation intermixed with both degenerated and viable neutrophils (fibrinopurulent exudate) (Figure 2). A moderate and predominantly perivascular, lymphohistiocytic and neutrophilic infiltrate were noted in the pons, cerebellar and cortical neuropil along with multifocal areas of hemorrhage in the cerebellum and white matter vacuolization in pons. In the cortex, several blood vessels presented a lymphoplasmacytic and neutrophilic infiltrate with luminal accumulation of fibrin (thrombi). The lumen of the fourth ventricle and the spinal cord central canal presented moderate to marked amounts of fibrin and neutrophils (some degenerated). A moderate lymphohistiocytic and neutrophilic infiltrate was observed in the efferent spinal cord ganglia. The CNS findings were consistent with a diffuse and severe fibrinopurulent meningoencephalomyelitis. Spleen, liver, kidneys, lungs, joints and gastrointestinal tract showed no macroscopic or histopathologic abnormalities.

A swab from the purulent material present in the CNS was collected and placed on Muller-Hinton agar (Difco, EUA) supplemented with 5\% sheep blood and on MacConkey agar (Difco, EUA). After a 24-hour incubation period at $37^{\circ} \mathrm{C}$ in aerobic condition, pure colonies with morphology suggestive of Salmonella spp. were isolated (RAMOS et al., 2018) and submitted to a polymerase chain reaction (PCR) test (KWANG et al., 1996). Following confirmation of the identity of the bacterium, serotyping was performed by antigenic characterization according to Grimont \& Weill (2007), which confirmed it as Salmonella enterica subsp enterica serovar Typhimurium.

The isolate was submitted to an antimicrobial susceptibility test by disk diffusion (LUBBERS, 2013), which included: ceftriaxone (30 $\mu \mathrm{g})$, gentamicin $(10 \mu \mathrm{g})$, cephalotin $(30 \mu \mathrm{g})$, ampicillin $(10 \mu \mathrm{g})$, chloramphenicol $(30 \mu \mathrm{g})$, trimethropim/sulfamethoxazole $(25 \mu \mathrm{g})$, ceftiofur $(30 \mu \mathrm{g})$, enrofloxacin $(10 \mu \mathrm{g})$ and ciprofloxacin (5 $\mu \mathrm{g})$ (DME, Brasil). It was resistant to cephalotin and ampicillin and intermediate resistant to enrofloxacin.

The diagnosis of fibrinopurulent meningoencephalomyelitis caused by $S$. Typhimurium in the foal from this report was based on clinical and pathology findings, associated with culture and identification of the bacterium. Clinical signs and macroscopic and histopathologic findings are consistent with those described previously in cases of equine bacterial meningoencephalolmyelitis (PELLEGRINI-MASINI \& LIVESEY, 2006; TOTH et al., 2012, STUART et al., 1973; PATTERSONKANE et al., 2001). Streptococcus equi subsp equi, $S$. aureus and E. coli, are more frequently described as the etiologic agent of meningoencephalomyelitis 


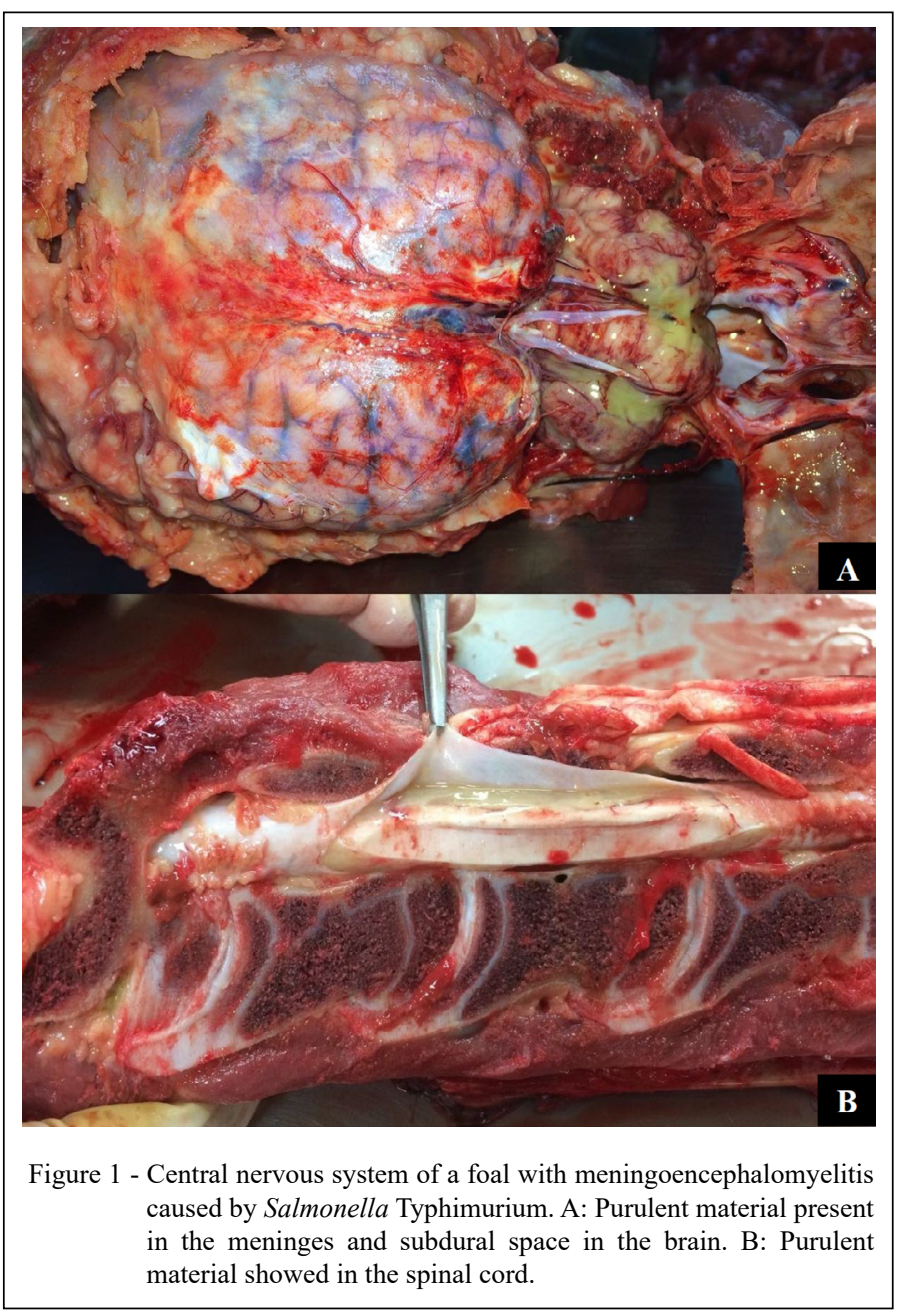

in horses (FINNO et al. 2006; MITCHELL et al., 2006; PELLEGRINI-MASINI \& LIVESEY, 2006; TOTH et al., 2012), but Salmonella spp. infection is not uncommon in foals and can lead to bacteremia, an important risk factor for the development of meningitis (SMITH, 1981; PATTERSON-KANE et al., 2001).

Bacteria can colonize the CNS by four major routes: osteitis/ erosion of the skull, hematogenous spread, spread through cranial nerves and direct inoculation by traumatic brain injury (TOTH et al., 2012; BACH et al., 2014). Neonates are particularly susceptible to bacterial meningitis due to their immature immune system, more permeable blood-brain barrier compared to adults, failure of passive transfer and inadequate umbilical care (common portal of entry for bacteria) (MITCHELL et al., 2006). The foal from this report had no history and signs of trauma and no evidence of gastrointestinal disease on clinical and post mortem examination. These findings associated with the presence of omphalophlebitis suggested that the umbilicus could have been the portal of entry in this case. Failure of passive transfer cannot be ruled out as another risk factor for this foal.

Even though reports of meningitis caused by Salmonella spp. are rare in animals, there are several reports of $S$. Typhimurium causing meningitis in humans, especially children (CHIU et al., 2002; ADHIKARY et al., 2013; KEDDY et al., 2015). In one report of meningoencephalitis caused by $S$. Typhimurium in a foal, no changes in the spinal cord were described. (STUART et al., 1973). In another report, $S$. Agona was isolated from a foal with meningoencephalomyelitis. This foal showed neurologic signs in addition to diarrhea and a 


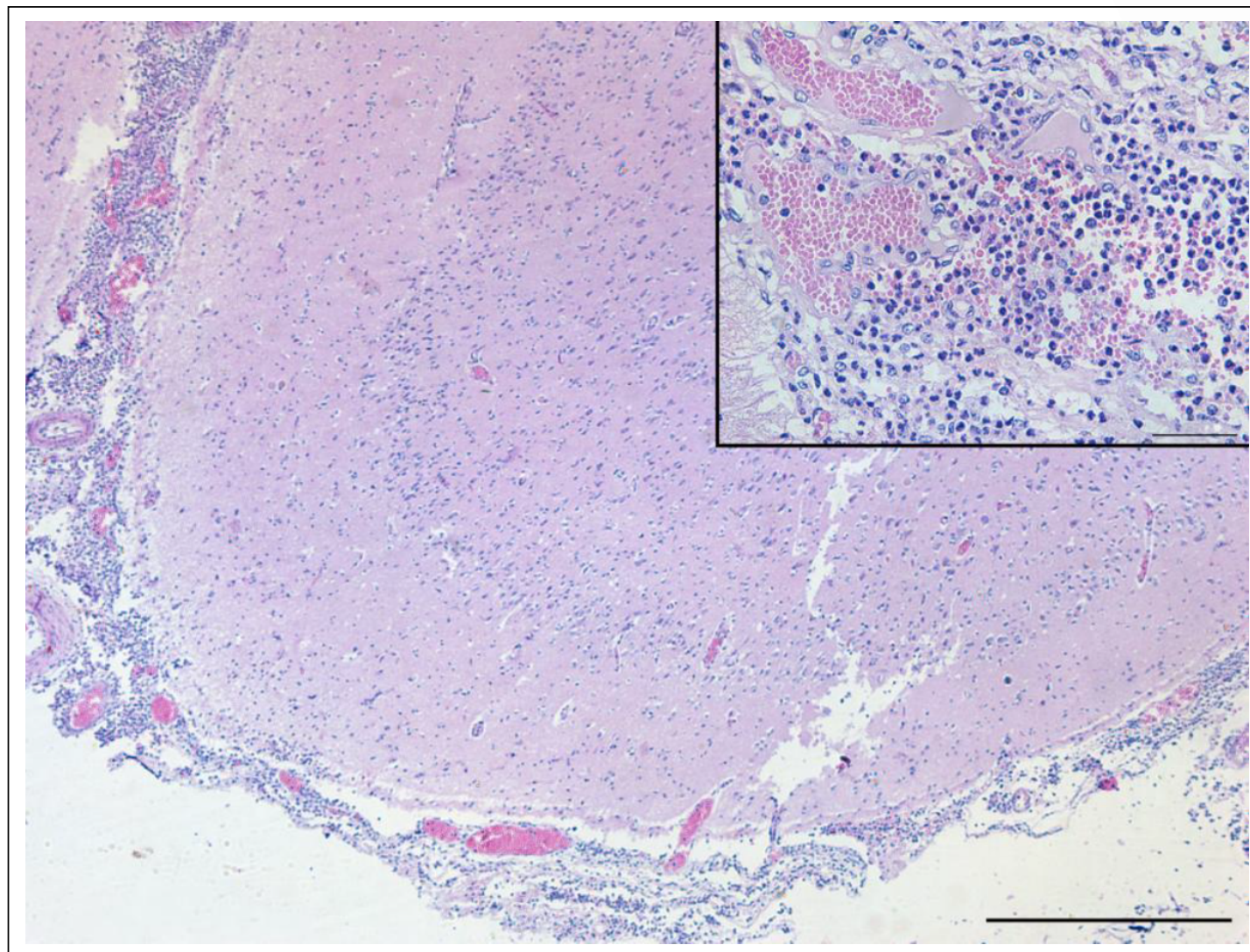

Figure 2 - The meninges were markedly thickened by moderate numbers of degenerated and viable neutrophils intermixed with fibrin. H\&E; Bar $=500$ um.

positive blood culture (PATTERSON-KANE et al., 2001). A similar case was described in a calf with neuropathy and omphalophlebitis caused by $S$. Dublin (COURA et al., 2015).

Apart from being capable of causing meningoencephalitis or meningoencephalomyelitis in foals, diarrhea in horses from different ages, septicemia in foals and other clinical manifestations, $S$. Typhimurium is an important zoonotic agent that has great impact on public health (STUART et al., 1973; SMITH, 1981; CUMMINGS, 2016; MORNINGSTAR-SHAW, 2016). This serotype is the most frequently isolated in cases of human salmonellosis worldwide, with 1,2 million cases and 450 deaths registered every year in the United States alone (FERNANDES et al., 2006; SCALLAN et al., 2011). Salmonellosis is also considered an occupational disease, so transmission is greater in people that work closely with infected animals
(CHIA-PING et al., 2017). Diagnosis of salmonellosis is essential so that appropriate methods to decrease zoonotic transmission can be instituted.

Considering the increasing number of multidrug resistant infections and the zoonotic risk associated with $S$. Typhimurium, the isolate was submitted to an antimicrobial susceptibility test, which included antibiotics commonly used in foals and frequently used for treatment of salmonellosis (PARVATHI et al., 2011; OIE, 2015; PATEL, 2015). The $S$. Typhimurium isolate was resistant to cephalotin and ampicillin, drugs that have a great importance in the treatment of infected animals and humans (WHO, 2017). The isolate also showed intermediate resistance to enrofloxacin, a quinolone exclusively used in veterinary medicine and considered critically important by the OIE for the treatment of bacterial diseases associated with septicemia, respiratory and enteric diseases (OIE, 2015). 
This is the first report describing inflammatory lesions associated with Salmonella Typhimurium in both brain and spinal cord of a foal. Salmonellosis should be considered a differential diagnosis for neurologic disease in foals, even in the absence of gastrointestinal disease.

\section{ACKNOWLEDGEMENTS}

The pathology and microbiology research carried out in this case were supported by Coordenação de Aperfeiçoamento de Pessoal de Nível Superior (CAPES), Conselho Nacional de Desenvolvimento Científico e Tecnológico (CNPq), Fundação de Amparo a Pesquisa do Estado de Minas Gerais (FAPEMIG) and Pró-Reitoria de Pesquisa, Universidade Federal de Minas Gerais (PRPq/UFMG).

\section{BIOETHICS AND BIOSSECURITY COMMITTEE APPROVAL}

We authors of the article entitled "Salmonella Typhimurium - associated meningoencephalomyelitis in a foal" declared, for all due purposes, the project that gave rise to the present data of the same has not been submitted for evaluation to the Ethics Committee of the University /Research Institute "Universidade Federal de Minas Gerais"(UFMG), but we are aware of the content of the Brazilian resolutions of the National Council for Control of Animal Experimentation - CONCEA "http://www. mct.gov.br/index.php/content/view/310553.html" if it involves animals. This is a case report of a sick foal that was brought to the Equine Hospital - UFMG by the owner, seeking medical advice and treatment. Therefore, the diagnostic procedures and treatment plan were necessary and are part of the clinic's routine.

Thus, the authors assume full responsibility for the presented data and are available for possible questions, should they be required by the competent authorities.

\section{DECLARATION OF CONFLICT OF INTERESTS}

The authors declare no conflict of interest. The founding sponsors had no role in the design of the study; in the collection, analyses, or interpretation of data; in the writing of the manuscript, and in the decision to publish the results.

\section{AUTHORS' CONTRIBUTIONS}

All authors critically revised the manuscript and approved the final version.

\section{REFERENCES}

ADHIKARY, R. et al. Salmonella typhimurium meningitis in infancy. Indian. J. Crit. Care Med., v.17, p.392-3, 2013. Available from: <https://www.ncbi.nlm.nih.gov/pmc/articles/ PMC3902579/>. Accessed: Jun. 12, 2019. doi: 10.4103/09725229.123464.

BACH, F.S. et al. Bacterial meningitis after sinus surgery in five adult horses. Vet. Surg., v. 43, p. 697-703, 2014. Available from:
$<$ https://www.ncbi.nlm.nih.gov/pubmed/24467610>. Accessed: Jun. 12, 2019. doi: 10.1111/j.1532-950X.2014.12132.x.

CHIA-PING, S. et al. Occupational Distribution of Campylobacteriosis and Salmonellosis Cases-Maryland, Ohio, and Virginia, 2014. Morb. Mortal Wkly Rep., v.66, n.32, p.850853, 2017. Available from: <https://www.ncbi.nlm.nih.gov/ pubmed/28817554>. Accessed: Jun. 12, 2019. doi: 10.15585/ mmwr.mm6632a4.

CHIU, C.H. et al. Characterization of a laboratory-derived, highlevel Ampicillin resistant Salmonella enterica serovar typhimurium strain that caused meningitis in an infant. Antimicrob. Agents and Chemother., v. 46, n. 5, p. 1604-1606, 2002. Available from: $<$ https://www.ncbi.nlm.nih.gov/pubmed/11959613>. Accessed: Jun. 12, 2019. doi: 10.1128/aac.46.5.1604-1606.2002.

COURA, F.M. et al. Systemic and enteric salmonellosis in calves Semina. Ciênc. Agrár., v.36, n.3, p.2041-2046, 2015. Available from: $\quad<$ http://www.uel.br/revistas/uel/index.php/semagrarias/ article/view/19586/16467>. Accessed: Jun. 12, 2019. doi: 10.5433/1679-0359.2015v36n3Sup11p2041.

LUBBERS, B. V. et al. Performance standards for antimicrobial disk and dilution susceptibility tests for bacteria isolated from animals. Pennsylvania: CLINICAL AND LABORATORY STANDARDS INSTITUTE (CLSI), 2013. v.33.

PATEL, J.B. Performance Standards for Antimicrobial Susceptibility Testing. Pennsylvania: CLINICAL AND LABORATORY STANDARDS INSTITUTE (CLSI), 2015. v. 35.

CUMMINGS, K.J. Antimicrobial resistance trends among Salmonella isolates obtained from horses in the northeastern United States (2001-2013). A. J. V. R., v. 77, n. 5, p. 505513, 2016. Available from: <https://www.ncbi.nlm.nih.gov/ pubmed/27111018>. Accessed: Jun. 12, 2019. doi: 10.2460/ ajvr.77.5.505.

FERNANDES, S.A. et al. Salmonella serovars isolated from humans in Sao Paulo State, Brazil, 1996-2003. Rev. Inst. Med. Trop. Sao Paulo, v. 48, n. 4, p. 179-184, 2006. Available from: $<$ https://www.ncbi.nlm.nih.gov/pubmed/17119671>. Accessed: Jun. 12, 2019. doi: 10.1590/s0036-46652006000400001.

FINNO, C. et al. Streptococcus equi meningoencephalomyelitis in a foal. J. Am. Vet. Med. Assoc., v. 229, n. 5, p. 721724, 2006. Available from: <https://www.ncbi.nlm.nih.gov/ pubmed/16948585>. Accessed: June.12, 2019. doi:10.2460/ javma.229.5.721.

GRIMONT, P.A.D.; WEILL F.X. Antigenic formulae of the Salmonella serovars. Paris: Institut Pasteur, 2007. p. 1-166.

JUFFO, G.D. et al. Equine salmonellosis in southern Brazil. Trop. Anim. Health Prod., v.49, n.3, p.475-482, 2017. Available from: $<$ https://www.ncbi.nlm.nih.gov/pubmed/28013440>. Accessed: Jun. 12, 2019. doi:10.1007/s11250-016-1216-1.

KEDDY, K.H. et al. Clinical and microbiological features of Salmonella meningitis in a South African population, 2003-2013. Clin. Infect. Dis,. v.61 n.4, p.272-282, 2015. Available from: $<$ https://www.ncbi.nlm.nih.gov/pubmed/26449942>. Accessed: Jun. 12, 2019. doi:10.1093/cid/civ685. 
KWANG, J. et al. Use of the polymerase chain reaction for Salmonella detection. Lett. Appl. Microbiol., v.22, p.4651, 1996. Available from: <https://www.ncbi.nlm.nih.gov/ pubmed/8588887>. Accessed: Jun. 12, 2019. doi: 10.1111/j.1472765X.1996.tb01106.x.

MITCHELL, E. et al. Bacterial meningitis in five mature horses. Equine vet. Educ., v.18, n.5, p.249-255, 2006. Available from: $<$ https://onlinelibrary.wiley.com/doi/pdf/10.1111/j.2042-3292.2006. tb00457.x>. Accessed: Jun. 12, 2019. doi: 10.1111/j.20423292.2006.tb00457.x.

PARVATHI, A. et al. Comparative virulence genotyping and antimicrobial susceptibility profiling of environmental and clinical Salmonella enterica from Cochin, India. Curr. Microbiol., v.62, p.21-26, 2011. Available from: <https://www.ncbi.nlm.nih.gov/ pubmed/20490498>. Accessed: Jun. 12, 2019. doi: 10.1007/ s00284-010-9665-7.

PATTERSON-KANE, J.C. et al. Meningoencephalomyelitis in a foal due to Salmonella agona infection. N. Z. Vet. J., v. 49, p. 159-161, 2001. Available from: <https://www.ncbi.nlm nih.gov/pubmed/16032184>. Accessed: June.12, 2019. doi: 10.1080/00480169.2001.36224.

PELLEGRINI-MASINI, A.; LIVESEY, L.C. Meningitis and encephalomyelitis in Horses. Vet. Clin. Equine, v.22, p.553589, 2006. Available from: <https://www.ncbi.nlm.nih.gov/ pubmed/16882487>. Accessed: Jun. 12, 2019. doi: 10.1016/j. cveq.2006.03.003.

SCALLAN, E. et al. Foodborne illness acquired in the United States-major pathogens. Emerg. Infect. Dis., v.17, n.1, p.715, 2011. Available from: <https://www.ncbi.nlm.nih.gov/pmc/ articles/PMC3375761/>. Accessed: Jun. 12, 2019. doi: 10.3201/ eid1701.P11101.

SMITH, B.P. Equine salmonellosis: A contemporary view. Equine Vet. J., v.13, n.3, p.147-151, 1981. Available from: <https:// onlinelibrary.wiley.com/doi/pdf/10.1111/j.2042-3306.1981. tb03471.x>. Accessed: Jun. 12, 2019. doi: 10.3201/eid1701.P11101.
RAMOS, C.P. et al. Identification and characterization of Escherichia coli, Salmonella spp., Clostridium perfringens, and $C$. difficile isolates from reptiles in Brazil. BioMed Res. Int., 2019. Available from: <https://www.hindawi.com/ journals/bmri/2019/9530732/>. Accessed: Jun. 12, 2019. doi: $10.1155 / 2019 / 9530732$.

STUART, B.P. et al. Salmonella-induced meningoencephalitis in a foal. J. Am. Vet. Med. Assoc., v.162, n.3 p.211-3, 1973. Available from: <https://www.ncbi.nlm.nih.gov/ pubmed/4566997>. Accessed: Jun. 12, 2019.

TOTH, B. et al. Meningitis and meningoencephalomyelitis in horses: 28 cases (1985-2010). J. Am. Vet. Med. Assoc., v.240, n.5, 2012. Available from: <https://www.ncbi.nlm.nih.gov/pubmed/22332628>. Accessed: Jun. 12, 2019. doi: 10.2460/javma.240.5.580.

MORNINGSTAR-SHAW, B.R. et al. Salmonella Serotypes Isolated from Animals and Related Sources. Ames: United States Department of Agriculture (USDA), National Veterinary Services Laboratories, 2016. Available from: <https://www.cdc. gov/nationalsurveillance/pdfs/salmonella-serotypes-isolatedanimals-and-related-sources-508.pdf $>$. Accessed: Aug. 17, 2018.

VIU, J. et al. Clinical findings in 10 foals with bacterial meningoencephalitis. Equine Vet. J., v. 44, p. 100-104, 2012. Available from: <https://www.ncbi.nlm.nih.gov/pubmed/22594036>. Accessed: Jun. 12, 2019. doi: 10.1111/j.2042-3306.2011.00508.x.

WORLD ORGANISATION FOR ANIMAL HEALTH (OIE). List of antimicrobial agents of veterinary importance. OIE International Committee, p.1-9, 2015. Available from: $<$ http://www. oie.int/fileadmin/Home/eng/Our_scientific_expertise/docs/pdf/Eng_ OIE_List_antimicrobials_May2015.pdf >. Accessed: Jun. 12, 2019.

WORLD HEALTH ORGANIZATION (WHO). Critically important antimicrobials for human medicine - 5th rev. Geneva, Switzerland, 2017. Available from: <https:/apps.who.int/iris/ bitstream/handle/10665/255027/9789241512220-eng.pdf;jsessio nid=D9F7D39E2B9447356493F4D4A9A8F842? sequence $=1>$. Accessed: Jun. 12, 2019. 